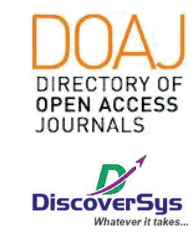

Published by DiscoverSys

\title{
Gambaran pengetahuan, sikap, dan praktik ibu balita terhadap penatalaksanaan diare pada anak balita di wilayah kerja Puskesmas Abang 1
}

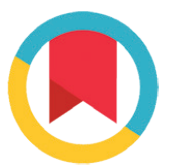

CrossMark

\author{
Made Rahayu Suryapramita Dusak, ${ }^{1 *}$ Yetty Sukmayani, ${ }^{1}$ Stephanie Apriliana Hardika, ${ }^{1}$ \\ Luh Putu Ariastuti ${ }^{2}$
}

\section{ABSTRACT}

Background: Diarrhea is one of health problem worldwide, which is the second lead cause of death in under five years old children. Diarrhea is still found in the top ten diseases with most visits in Puskesmas Abang I, Karangasem. Data provided by survey of 10 mothers is showing most of them (70\%) have given inappropriate diarrhea management. It means there is inappropriate behavior of mothers in managing diarrhea at home.

Methods: This study is descriptive cross-sectional study that includes 62 mothers of under five years old children in Puskesmas Abang I. The aim of this study is to know knowledge, atittudes, and practices of mothers regarding management of diarrhea in under five years old children in Puskesmas Abang I. This study uses purposive sampling method in choosing three villages in Puskesmas Abang I and the sampling technique is using snowballing method. The data is collected by doing interview-based questionnaire.

Result: In this study, knowledge of mothers of under five years old children about diarrhea majority in the poor category (91.9\%).

Conclusion: Mothers of under five years old children has lack of knowledge in diarrhea management, in which most of them still have negative response in acute management of children that defecate more watery than usual and negative response in diarrhea management that is enough with oral rehydration solution only. Beside that, most of mothers also have inappropriate practices in the use of traditional medicine and sweet tea as diarrhea management.
${ }^{1}$ Program Studi Pendidikan Dokter ${ }^{2}$ Bagian Ilmu Kedokteran Komunitas dan IImu Kedokteran Pencegahan

Fakultas Kedokteran Universitas Udayana

\section{*Korespodensi:}

Made Rahayu Suryapramita Dusak, Program Studi Pendidikan Dokter, Fakultas Kedokteran Universitas Udayana

suryapramita93@gmail.com

Received: 2018-02-07

Accepted: 2018-02-21

Published: 2018-05-1

Keywords: knowledge, attitudes, practices, mothers, diarrhea management Cite This Article: Dusak, M.R.S., Sukmayani, Y., Hardika, S.A., Ariastuti, L.P. 2018. Gambaran pengetahuan, sikap, dan praktik ibu balita terhadap penatalaksanaan diare pada anak balita di wilayah kerja Puskesmas Abang 1. Intisari Sains Medis 9(2): 85-94. D0I: 10.1556/ism.v9i2.168

\section{ABSTRAK}

Latar Belakang: Diare merupakan salah satu permasalahan kesehatan dunia yang menjadi penyebab utama kedua kematian anak dibawah lima tahun. Diare dan gastroenteritis dengan penyebab infeksi juga ditemukan masih termasuk ke dalam 10 besar penyakit dengan kunjungan terbanyak di Puskesmas Abang I, Karangasem. Edukasi kesehatan mengenai diare pada balita serta penanganannya penting untuk keefektifan penatalaksanaan kasus diare. Berdasarkan survei singkat yang dilakukan pada 10 orang ibu balita terkait dengan penanganan diare di rumah didapatkan bahwa sebagian besar (70\%) ibu balita memberikan penanganan yang kurang tepat. Hal ini menunjukkan kecenderungan perilaku yang kurang tepat dalam penatalaksanaan diare di rumah.

Metode: Penelitian ini merupakan studi deskriptif cross sectional dengan melibatkan 62 subjek penelitian yang merupakan ibu balita di wilayah kerja Puskesmas Abang I. Penelitian ini dilakukan bertujuan untuk mengetahui gambaran pengetahuan, sikap, dan praktik ibu balita dalam penatalaksanaan diare pada anak balita di wilayah kerja Puskesmas Abang I. Penelitian ini menggunakan metode purposive sampling untuk memilih tiga desa yang berada di wilayah kerja Puskesmas Abang I dan pengambilan sampel dilakukan dengan snowballing method. Cara pengumpulan data pada penelitian ini dengan melakukan wawancara berbasis kuesioner.

Hasil: Pada penelitian ini didapatkan gambaran pengetahuan mengenai diare pada balita mayoritas dalam kategori kurang (91,9\%). Simpulan: ibu balita memiliki pengetahuan kurang terkait penatalaksanaan diare pada balita, dimana sebagian besar ibu balita masih merespon negatif dalam penanganan awal saat anak mengalami buang air besar lebih encer dari biasanya serta penanganan diare cukup dengan oralit saja. Selain itu, sebagian besar ibu balita juga masih memiliki praktik yang kurang tepat terkait penggunaan obat tradisional dan pemberian teh manis pada balita dengan diare. 


\section{PENDAHULUAN}

Diare merupakan salah satu permasalahan kesehatan dunia yang patut menjadi perhatian global. Berdasarkan data World Health Organization (WHO) dilaporkan bahwa terdapat hampir 1,7 miliar kasus diare terjadi di dunia tiap tahunnya. ${ }^{1}$ Diare merupakan penyebab utama kedua kematian anak setelah pneumonia yaitu sebesar $11 \%$ dari seluruh kematian anak dibawah 5 tahun. ${ }^{2}$ Setiap tahunnya, 1,9 juta anak dibawah 5 tahun meninggal akibat diareterutama di negara berkembang. Sekitar 78\% kematian tersebut terjadi di daerah Afrika dan Asia Tenggara. Diperkirakan di negara berkembang setiap anak dibawah 3 tahun mengalami 3 kali episode diare akut setiap tahunnya. Setiap episode tersebut akan menekan nutrisi yang dibutuhkan untuk pertumbuhan. Oleh karena itu, diare juga menjadi penyebab utama malnutrisi pada anak. ${ }^{3}$

Sebagai negara berkembang, Indonesia juga masih memiliki angka morbiditas dan mortalitas yang tinggi akibat penyakit diare. Berdasarkan hasil survei morbiditas dari Subdit Diare Departemen Kesehatan, dari tahun 2000 sampai dengan 2010 terdapat kecenderungan insiden diare meningkat. Pada tahun 2000, insiden rate penyakit diare sebesar 301/1000 penduduk, tahun 2003 naik menjadi $374 / 1000$ penduduk, tahun 2006 naik menjadi 423/1000 penduduk dan tahun 2010 menjadi 411/1000 penduduk. Berdasarkan laporan Riset Kesehatan Dasar tahun 2007 menurut kelompok umur, penyakit diare tersebar di seluruh kelompok umur dengan prevalensi tertinggi pada anak dibawah 5 tahun (1-4 tahun) yaitu sebesar 16,7\%. Diare juga menjadi penyebab terbesar kematian anak balita (12-59 bulan) yaitu $25,2 \%{ }^{4}$

Tingginya morbiditas dan mortalitas diare mendorong WHO dan UNICEF untuk mengeluarkan pedoman penatalaksanaan diare yang ditindaklanjuti oleh Departemen Kesehatan Republik Indonesia untuk menerbitkan buku Pedoman Pengendalian Penyakit Diare. Secara garis besar, tatalaksana diare pada anak yang direkomendasikan adalah dengan melanjutkan pemberian makanan, menggantikan cairan yang keluar dengan oralit formula baru dan pemberian suplemen zinc. Oralit formula baru yang direkomendasikan dapat menurunkan muntah, menurunkan tinja yang keluar, menurunkan kemungkinan hipernatremia dan menurunkan keperluan infus intravena dibandingkan dengan standar ORS yang sebelumnya. ${ }^{3}$ Selain itu dengan pemberian zinc dikatakan dapat menurunkan 25\% durasi dari episode diare dan berkaitan dengan penurunan volume tinja sebesar $30 \%{ }^{1}$

Penanganan penyakit diare sangat sederhana, terjangkau, dan tidak memerlukan teknologi yang canggih. Namun dalam implementasinya, penatalaksanaan sesuai dengan standar masih sangat kurang. Secara global, hanya $40 \%$ anak dibawah 5 tahun dengan diare yang mendapatkan terapi rehidrasi oral dan melanjutkan pemberian makanan sesuai dengan rekomendasi. ${ }^{5}$ Gambaran perilaku penanganan diare di rumah tangga menurut hasil survei morbiditas diare tahun 2010 yang dilakukan oleh Kementerian Kesehatan RI menunjukkan bahwa dari 508 penderita, hanya $37 \%$ penderita yang diberikan cairan oralit dan hanya $7,28 \%$ penderita diberi larutan gula garam (LGG). Tatalaksana penyakit diare yang tidak tepat dan cepat dapat berdampak serius bagi penderitanya. Sebagian besar kematian akibat diare disebabkan oleh dehidrasi berat dan kehilangan cairan. ${ }^{6}$

Puskesmas Abang I merupakan salah satu Puskesmas yang terletak di Kabupaten Karangasem dengan luas wilayah kerja $47,19 \mathrm{~km}^{2}$, membawahi 8 desa dan 53 dusun dengan jumlah penduduk diperkirakan mencapai 36.794 jiwa. Berdasarkan laporan Puskesmas Abang 1 tahun 2014, diare dan gastroenteritis dengan penyebab infeksi masih termasuk ke dalam 10 besar penyakit dengan kunjungan terbanyak di Puskesmas Abang I yaitu menduduki peringkat kesepuluh dengan jumlah 434 kunjungan. Berdasarkan laporan dari pemegang program Pemberantasan Penyakit Menular (P2M) Diare dikatakan bahwa dari 58,1\% kasus diare yang ditangani di Puskesmas Abang I, dimana dari data tersebut terdapat 201 kasus (45\%) pada kelompok umur satu sampai empat tahun dan 244 (55\%) kasus pada kelompok umur lebih dari sama dengan lima tahun (Puskesmas Abang I, 2014). Kenyataan tersebut dapat disebabkan proyeksi penduduk yang terlalu besar, adanya masyarakat yang mencari pengobatan ke praktek swasta namun tidak terdata, dan adanya masyarakat yang melakukan penanganan sendiri.

Berdasarkan atas latar belakang tersebut, peneliti melakukan studi epidemiologi mengenai pengetahuan, sikap, dan praktik ibu anak balita tentang penatalaksanaan diare pada anak balita di wilayah kerja Puskesmas Abang I.

\section{METODE}

Penelitian ini menggunakan pendekatan deskriptif kuantitatif dengan desain cross-sectional untuk memperoleh gambaran pengetahuan, sikap, dan praktik ibu balita tentang penatalaksanaan pada balita dengan diare. Penelitian ini dilakukan pada Mei sampai Juni 2015. Sampel dalam penelitian ini adalah seluruh ibu balita di wilayah kerja Puskesmas Abang I, Kabupaten Karangasem yang memenuhi kriteria pengambilan sampel. kriteria inklusi sampel berupa wanita yang sudah menikah dan memiliki anak berusia kurang dari lima tahun yang pernah mengalami diare dalam setahun 
terakhir dan wanita yang mengasuh anaknya secara langsung. Sedangkan kriteria ekslusi adalah wanita yang tidak dapat membaca, menulis, dan berbicara, wanita yang menolak untuk menjadi sumber informasi. Penelitian ini menggunakan metode purposive sampling untuk memilih tiga desa yang berada di wilayah kerja Puskesmas Abang I yaitu Desa Abang, Pidpid, dan Kesimpar. Sebanyak 62 orang ibu balita yang menjadi sampel penelitian diambil dengan metode snowballing sampling.

Pengumpulan data dilakukan dengan cara mengisi kuesioner. Sebelum melakukan pengisian kuisioner dilakukan, responden dimintai persetujuan terlebih dahulu apakah bersedia untuk mengisi kuisioner atau tidak. Jika responden bersedia untuk mengisi kuisioner, selanjutnya responden diminta untuk menjawab secara lengkap pertanyaan berdasarkan kuesioner yang tersedia. Data yang telah terkumpul kemudian diolah dan dianalisis secara deskriptif

\section{HASIL}

Mayoritas responden berada dalam kelompok umur $14-16$ tahun yaitu sebesar $58 \%$ dari total responden. Usia rata-rata dari responden adalah 16.18. Mayoritas responden mengalami menarche pada usia $>12$ tahun (64\%). Tidak ada responden yang memiliki riwayat benjolan pada payudara. Sedangkan terkait riwayat keluarga dengan kanker payudara, $2 \%$ dari responden memiliki riwayat keluarga dengan kanker payudara, dan $12 \%$ responden

\section{Tabel 1 Data Dasar Karakteristik Responden}

\begin{tabular}{lcc}
\hline & Frekuensi $(\boldsymbol{f})$ & Persentase (\%) \\
\hline Usia & & \\
15-24 Tahun & 9 & 14,5 \\
25-34 Tahun & 38 & 61,3 \\
35-49 Tahun & 15 & 24,2 \\
Paritas & & \\
Anak 1 & 25 & 40,3 \\
Anak 2 & 15 & 24,2 \\
Anak >2 & 22 & 35,5 \\
Tingkat Pendidikan & & \\
Tidak Sekolah & 6 & 9,7 \\
SD & 23 & 37,1 \\
SMP & 20 & 32,3 \\
SMA & 7 & 11,3 \\
S1/Akademi & 6 & 9,7 \\
\hline
\end{tabular}

Tabel 2 Gambaran Pengetahuan Responden Mengenai Diare pada Balita

\begin{tabular}{lcc}
\hline Tingkat Pengetahuan & Frekuensi $(\boldsymbol{f})$ & Persentase $(\%)$ \\
\hline Baik & 5 & 8,1 \\
Kurang & 57 & 91,9 \\
\hline
\end{tabular}

menyatakan tidak mengetahui apakah di dalam keluarganya terdapat riwayat kanker payudara atau tidak. Dari $2 \%$ responden yang memiliki riwayat keluarga dengan kanker payudara, mengisi keterangan bahwa keluarganya tersebut merupakan bibinya dan saat ini telah meninggal dunia.

Penelitian ini dilakukan pada ibu balita yang berdomisili di Desa Abang, Pidpid, dan Kesimpar, Kecamatan Abang, Kabupaten Karangasem. Pengumpulan data dilakukan melalui wawancara terstruktur yang berlangsung dari tanggal 10 Juni hingga 19 Juni 2015. Berdasarkan data yang diperoleh dari ibu balita yang berada di tiga desa tersebut didapatkan 62 responden yang memenuhi kriteria penelitian, dengan rincian seperti yang terlihat pada Tabel 1.

Karakteristik responden berdasarkan umur didapatkan bahwa sebanyak $61,3 \%$ responden penelitian ini berada dalam kelompok usia 25-34 tahun. Usia termuda dari responden penelitian ini adalah 19 tahun dan usia tertua adalah 45 tahun dengan rata-rata umur responden adalah 30,11 tahun. Berdasarkan tingkat pendidikan didapatkan tingkat pendidikan responden cenderung lebih banyak berpendidikan SD yakni sebanyak $37,1 \%$. Sementara itu, berdasarkan jumlah anaknya, mayoritas responden memiliki 1 anak yakni sebanyak 40,3\%, sisanya responden memiliki 2 anak dan lebih dari 2 anak masing-masing sebanyak $24,2 \%$ dan $35,5 \%$.

Berdasarkan hasil wawancara pada 62 responden, gambaran pengetahuan mengenai diare pada balita mayoritas dalam kategori kurang (91,9\%) (Tabel 2).

Berdasarkan Tabel 3 tampak beberapa aspek pengetahuan spesifik yang masih kurang. Dalam hal penularan penyakit diare, $36(58,1 \%)$ responden menganggap penyakit diare tidak menular. Sebagian besar responden kurang mengetahui diare dapat menular lewat air (71\%), makanan dan minuman $(67,7 \%)$, dan kotoran (71\%). Selain itu, terkait dengan penanganan awal diare, pengetahuan ibu tentang pemberian teh manis dan obat tradisional juga masih kurang yaitu berturut-turut sebanyak 46 $(74,2 \%)$ dan 37 (59,7\%). Pengetahuan ibu balita juga masih kurang $(80,6 \%)$ dalam hal pemberian tablet zinc pada balita dengan diare. Sebanyak $40(64,5 \%)$ juga tidak mengetahui tentang cara membuat larutan gula garam. Terdapat 17 (27,4\%) ibu balita yang tidak mengetahui pemberian ASI saat diare tidak dihentikan. Pengetahuan terkait pola makan yang lebih sering pada balita yang sedang diare juga masih kurang pada sebagian besar ibu balita $(56,2 \%)$.

Pengetahuan responden yang kurang dapat diakibatkan oleh berbagai faktor yang kompleks dan saling mempengaruhi. Ada beberapa faktor yang diketahui berpengaruh terhadap tingkat pengetahuan seseorang, diantaranya usia, tingkat 
Tabel 3 Distribusi Responden Berdasarkan Pengetahuan Spesifik

\begin{tabular}{|c|c|c|c|c|}
\hline \multirow[b]{2}{*}{ Pengetahuan Spesifik } & \multicolumn{2}{|c|}{ Baik } & \multicolumn{2}{|c|}{ Kurang } \\
\hline & Frekuensi & Persentase & Frekuensi & Persentase \\
\hline Definisi Diare & 53 & 85,5 & 9 & 14,5 \\
\hline Penyebab Diare Kuman & 54 & 87,1 & 8 & 12,9 \\
\hline Penyebab Diare Air dan Makanan yang Kotor & 55 & 88,7 & 7 & 11,3 \\
\hline Penyebab Diare Susu Sapi & 26 & 41,9 & 36 & 58,1 \\
\hline Diare merupakan penyakit yang menular & 26 & 41,9 & 36 & 58,1 \\
\hline Penularan Air & 18 & 29 & 44 & 71 \\
\hline Tidak Menular Melalui Udara & 48 & 77,4 & 14 & 22,6 \\
\hline Penularan Makanan dan Minuman & 20 & 32,3 & 42 & 67,7 \\
\hline Penularan Kotoran & 18 & 29 & 44 & 71 \\
\hline Tanda Dehidrasi & 59 & 95,2 & 3 & 4,8 \\
\hline Penanganan Pertama Oralit & 55 & 88,7 & 7 & 11,3 \\
\hline Penanganan Pertama LGG & 44 & 77,4 & 14 & 22,6 \\
\hline Tidak Memberikan Teh Manis & 16 & 25,8 & 46 & 74,2 \\
\hline Tidak Memberikan Obat Anti Diare & 35 & 56,5 & 27 & 43,5 \\
\hline Tidak Memberikan Obat Tradisional & 25 & 40,3 & 37 & 59,7 \\
\hline Cara Membuat LGG & 22 & 35,5 & 40 & 64,5 \\
\hline Pemberian Tablet Zinc & 12 & 19,4 & 50 & 80,6 \\
\hline Pemberian ASI & 45 & 72,6 & 17 & 27,4 \\
\hline Pola Makan Lebih Sering & 29 & 46,8 & 33 & 56,2 \\
\hline
\end{tabular}

Tabel 4 Distribusi Frekuensi Beberapa Variabel Terhadap Pengetahuan Responden Mengenai Penanganan Diare pada Balita

\begin{tabular}{|c|c|c|c|c|}
\hline \multirow[b]{3}{*}{ Karakteristik Responden } & \multicolumn{4}{|c|}{ Pengetahuan } \\
\hline & \multicolumn{2}{|c|}{ Baik } & \multicolumn{2}{|c|}{ Kurang } \\
\hline & Frekuensi (f) & Persentase (\%) & Frekuensi (f) & Persentase (\%) \\
\hline \multicolumn{5}{|l|}{ Umur } \\
\hline $15-24$ & 2 & $22,2 \%$ & 7 & $77,8 \%$ \\
\hline $25-34$ & 1 & $2,6 \%$ & 37 & $97,4 \%$ \\
\hline $35-49$ & 2 & $13,3 \%$ & 13 & $86,7 \%$ \\
\hline \multicolumn{5}{|l|}{ Tingkat Pendidikan } \\
\hline Tidak Sekolah & 0 & $0,0 \%$ & 6 & $100,0 \%$ \\
\hline SD & 1 & $4,3 \%$ & 22 & $95,7 \%$ \\
\hline SMP & 2 & $10,0 \%$ & 18 & $90,0 \%$ \\
\hline SMA & 1 & $14,3 \%$ & 6 & $85,7 \%$ \\
\hline S1/Akademi & 1 & $16,7 \%$ & 5 & $83,3 \%$ \\
\hline \multicolumn{5}{|l|}{ Paritas } \\
\hline 1 anak & 1 & $4,0 \%$ & 24 & $96,0 \%$ \\
\hline 2 anak & 3 & $20,0 \%$ & 12 & $80,0 \%$ \\
\hline$>2$ anak & 1 & $4,5 \%$ & 21 & $95,5 \%$ \\
\hline
\end{tabular}

pendidikan, dan paritas. Analisis bivariat dengan melakukan cross table terhadap variabel pengetahuan dan masing-masing variabel dari karakteristik responden dapat dilihat pada Tabel 4 .
Tabel 4 menunjukkan distribusi tingkat pengetahuan menurut umur, tingkat pendidikan, dan paritas. Pada penelitian ini, responden yang didominansi oleh kelompok usia 25-34 tahun didapatkan sebanyak 37 
Tabel 5 Distribusi Responden Berdasarkan Sikap Spesifik

\begin{tabular}{|c|c|c|c|c|}
\hline \multirow[b]{2}{*}{ Sikap Spesifik } & \multicolumn{2}{|c|}{ Positif } & \multicolumn{2}{|c|}{ Negatif } \\
\hline & Frekuensi (f) & Persentase (\%) & Frekuensi (f) & Persentase (\%) \\
\hline Penanganan awal & 48 & 77,4 & 14 & 22,6 \\
\hline Pemberian oralit untuk mencegah kekurangan cairan & 57 & 91,9 & 5 & 8,1 \\
\hline BAB lebih encer dari biasanya tidak segera ke puskesmas atau dokter & 11 & 17,7 & 51 & 82,3 \\
\hline Pengobatan diare biaya sedikit & 53 & 85,5 & 9 & 14,5 \\
\hline Pengganti oralit di rumah & 56 & 90,3 & 6 & 9,7 \\
\hline Tidak menggunakan larutan oralit sudah dibuat $>24$ jam & 58 & 93,5 & 4 & 6,5 \\
\hline Penangangan diare tidak cukup dengan oralit & 20 & 32,3 & 42 & 67,7 \\
\hline Cuci tangan untuk mencegah diare & 59 & 95,2 & 3 & 4,8 \\
\hline ASI eksklusif untuk mencegah diare & 45 & 72,6 & 17 & 27,4 \\
\hline Penyuluhan diare dan penanganannya & 61 & 98,4 & 1 & 1,6 \\
\hline
\end{tabular}

Tabel 6 Distribusi Sikap Spesifik Terkait Tindak Lanjut BAB Lebih Encer dari Biasanya Berdasarkan Pengetahuan

\begin{tabular}{|c|c|c|c|}
\hline \multirow{2}{*}{$\begin{array}{l}\text { Kategori } \\
\text { Pengetahuan } \\
\text { f (\%) }\end{array}$} & \multicolumn{2}{|c|}{$\begin{array}{c}\text { Kategori Sikap } \\
\text { Tindak Lanjut BAB Lebih Encer dari Biasanya } \\
\text { f (\%) }\end{array}$} & \multirow{2}{*}{$\begin{array}{l}\text { Total } \\
\text { f (\%) }\end{array}$} \\
\hline & Positif & Negatif & \\
\hline Baik & $2(40)$ & $3(60)$ & $5(100)$ \\
\hline Kurang & $9(15,8)$ & $48(84,2)$ & $57(100)$ \\
\hline Total & $11(17,7)$ & $51(82,3)$ & $62(100)$ \\
\hline
\end{tabular}

Tabel 7 Distribusi Sikap Spesifik Terkait Penanganan Diare Cukup Oralit Berdasarkan Pengetahuan

\begin{tabular}{lccc}
\hline \multirow{2}{*}{$\begin{array}{l}\text { Kategori } \\
\text { Pengetahuan } \\
\mathbf{f ( \% )}\end{array}$} & \multicolumn{2}{c}{$\begin{array}{c}\text { Kategori Sikap } \\
\text { Penanganan Diare Cukup Oralit } \\
\mathbf{f}(\%)\end{array}$} & \\
\cline { 2 - 3 } & Positif & Negatif & $\begin{array}{c}\text { Total } \\
\mathbf{f}(\%)\end{array}$ \\
\hline Baik & $2(40)$ & $3(60)$ & $5(100)$ \\
Kurang & $18(31,6)$ & $39(68,4)$ & $57(100)$ \\
Total & $20(32,3)$ & $42(67,7)$ & $62(100)$ \\
\hline
\end{tabular}

responden (97,4\%) yang berpengetahuan kurang dan hanya 1 responden $(2,6 \%)$ yang memiliki pengetahuan baik mengenai penanganan diare pada balita.

Berdasarkan tingkat pendidikannya, seluruh responden yang tidak bersekolah didapatkan memiliki pengetahuan kurang mengenai penanganan diare pada balita. Pada penelitian ini juga ditemukan $16,7 \%$ responden yang berpendidikan S1/akademi memiliki tingkat pengetahuan yang baik mengenai penanganan diare pada balita.

Selain itu, berdasarkan jumlah anak yang dimiliki responden didapatkan $4 \%$ responden yang memiliki 1 anak berpengetahuan baik, 20\% responden yang memiliki 2 anak berpengetahuan baik, dan 4,5\% responden yang memiliki $>2$ anak berpengetahuan baik dalam menangani diare pada balita.
Sikap responden mengenai penanganan diare pada balita dilihat berdasarkan jawaban responden dari pertanyaan pada kuesioner. Pertanyaan tentang sikap ini berjumlah 10 pertanyaan dengan skor nilai terendah 1 dan nilai tertinggi 5. Sebaran responden berdasarkan jawaban pertanyaan tentang sikap responden mengenai penanganan diare pada balita tampak pada Tabel 5.

Dalam pernyataan bahwa pemberian oralit bertujuan mencegah kekurangan cairan, sebanyak 57 responden (91,9\%) memberikan sikap positif dan hanya 5 responden $(8,1 \%)$ memberikan sikap negatif. Sebanyak 51 responden $(82,3 \%)$ memberikan sikap negatif pada pernyataan anak dengan buang air besar lebih encer dari biasanya segera ke puskesmas atau dokter, dan hanya 17,7\% yang memberikan sikap positif. Dalam pernyataan bahwa penanganan diare cukup dengan oralit, $67,7 \%$ responden memberikan sikap negatif dan sisanya sebanyak 20 responden memberikan sikap positif. Selain itu, pada penelitian ini juga didapatkan mayoritas responden $(98,4 \%)$ memberikan sikap positif mengenai adanya penyuluhan diare beserta penanganannya.

Sikap seseorang juga dapat dipengaruhi oleh tingkat pengetahuan yang dimilikinya. Terdapat 2 aspek pernyataan spesifik sikap yang direspon negatif oleh sebagian besar ibu balita yang dinilai juga dipengaruhi oleh tingkat pengetahuan responden yakni dalam menyikapi tindak lanjut saat anak buang air besar encer lebih dari biasanya maka harus segera dibawa ke rumah sakit dan menyikapi pernyataan terkait penanganan diare cukup dengan oralit saja. Analisis bivariat dengan melakukan cross table terhadap variabel sikap spesifik dan variabel pengetahuan responden didapatkan hasil seperti yang terlihat dalam tabel 6 dan tabel 7. 
Tabel 8 Distribusi Responden Berdasarkan Praktik Spesifik

\begin{tabular}{|c|c|c|c|c|}
\hline \multirow[b]{2}{*}{ Praktik Spesifik } & \multicolumn{2}{|c|}{ Baik } & \multicolumn{2}{|c|}{ Buruk } \\
\hline & Frekuensi (f) & Persentase (\%) & Frekuensi (f) & Persentase (\%) \\
\hline $\begin{array}{l}\text { Tindak lanjut saat BAB lebih encer dari biasanya tidak langsung } \\
\text { membawa ke petugas kesehatan }\end{array}$ & 27 & 43,5 & 35 & 56,5 \\
\hline Makanan yang diberikan seperti biasa namun lebih sering & 60 & 96,8 & 2 & 3,2 \\
\hline Tidak menghentikan ASI & 47 & 75,8 & 15 & 24,2 \\
\hline Pemberian oralit atau larutan gula garam & 52 & 83,9 & 10 & 16,1 \\
\hline Pemberian tablet zinc & 13 & 21 & 49 & 79 \\
\hline Tindak lanjut saat diare disertai panas dan muntah & 62 & 100 & 0 & 0 \\
\hline Tidak menggunakan obat tradisional & 28 & 45,2 & 34 & 54,8 \\
\hline Pemberian cairan oralit terus-menerus sampai diare berhenti & 39 & 62,9 & 23 & 37,1 \\
\hline Tidak memberikan jus buah dan teh manis & 18 & 29 & 44 & 71 \\
\hline Penggunaan air matang yang dimasak mendidih & 57 & 91,9 & 5 & 8,1 \\
\hline
\end{tabular}

Tabel 9 Distribusi Praktik Pemberian Obat Tradisional Berdasarkan Pengetahuan

\begin{tabular}{lccc}
\hline $\begin{array}{l}\text { Kategori } \\
\text { Pengetahuan } \\
\mathbf{f}(\%)\end{array}$ & \multicolumn{2}{c}{$\begin{array}{c}\text { Kategori Praktik Spesifik } \\
\text { Pemberian Obat Tradisional f }(\%)\end{array}$} & $\begin{array}{c}\text { Total } \\
\mathbf{f}(\%)\end{array}$ \\
\cline { 2 - 3 } & Baik & Buruk & $5(100)$ \\
Baik & $5(100)$ & $0(0)$ & $57(100)$ \\
Kurang & $23(40,4)$ & $34(59,6)$ & $62(100)$ \\
Total & $28(45,2)$ & $34(54,8)$ & \\
\hline
\end{tabular}

\section{Tabel 10 Distribusi Praktik Pemberian Teh Manis Berdasarkan} Pengetahuan

\begin{tabular}{lccc}
\hline $\begin{array}{l}\text { Kategori } \\
\text { Pengetahuan } \\
\mathbf{f}(\%)\end{array}$ & \multicolumn{2}{c}{ Kategori Praktik Spesifik } \\
\cline { 2 - 3 } & \multicolumn{2}{c}{$\begin{array}{c}\text { Pemberian Teh Manis f (\%) } \\
\text { Baik }\end{array}$} & $\begin{array}{c}\text { Total } \\
\mathbf{f}(\%)\end{array}$ \\
\cline { 2 - 3 } Kurang & $2(40)$ & $3(60)$ & $5(100)$ \\
Total & $16(28,1)$ & $41(71,9)$ & $57(100)$ \\
\hline
\end{tabular}

Pada tabel 6 terlihat bahwa terdapat 48 responden $(84,2 \%)$ yang memiliki pengetahuan kurang dengan sikap negatif dan hanya 2 responden (40\%) berpengetahuan baik dengan sikap positif terhadap tindak lanjut lanjut saat anak buang air besar encer lebih dari biasanya.

Pada penelitian ini juga menemukan 39 responden $(68,4 \%)$ yang memiliki pengetahuan kurang dengan sikap negatif dan hanya 2 responden (40\%) berpengetahuan baik dengan sikap positif terhadap pernyataan penanganan diare cukup dengan oralit saja, seperti yang dapat terlihat dalam tabel 7 .

Praktik responden mengenai penanganan diare pada balita dilihat berdasarkan jawaban responden dari pertanyaan pada kuesioner. Sebaran responden berdasarkan jawaban pertanyaan tentang praktik responden mengenai penanganan diare pada balita tampak pada tabel 8 .

Hasil praktik responden mengenai pemberian makanan pada balita yang diare yakni dengan cara tetap memberikan makanan lunak sedikit-sedikit namun lebih sering, menunjukkan sebagian besar responden dengan jumlah 60 orang $(96,8 \%)$ telah melakukannya. Sebanyak 47 responden $(75,8 \%)$ tidak menghentikan pemberian ASI pada balita dengan diare. Sebagian besar responden $(83,9 \%)$ sudah memberikan oralit pada balita yang mengalami diare dengan cara yang benar. Namun, praktik dalam pemberian tablet zinc guna mempercepat penyembuhan belum dilakukan dengan baik, dimana $79 \%$ responden masih ditemukan memiliki praktik buruk. Penggunaan obat tradisional pada balita dengan diare juga masih sering dilakukan, dimana 34 responden $(54,8 \%)$ masih ditemukan memiliki praktik buruk. Selain itu, pemberian teh manis pada balita dengan diare juga masih sering dilakukan, dimana 44 responden $(71 \%)$ ditemukan masih memberikan teh manis saat anak mereka mengalami diare.

Praktik seseorang juga dapat dipengaruhi oleh tingkat pengetahuan yang dimilikinya. Terdapat 2 aspek pernyataan spesifik praktik yang kurang tepat yang masih dilakukan oleh sebagian besar ibu balita yang dinilai juga dipengaruhi oleh tingkat pengetahuan responden yakni praktik pemberian obat tradisional dan pemberian teh manis saat anak diare. Analisis bivariat dengan melakukan cross table terhadap variabel praktik spesifik dan variabel pengetahuan responden didapatkan hasil seperti yang terlihat dalam Tabel 9 dan Tabel 10.

Pada Tabel 9 terlihat bahwa seluruh responden yang memiliki pengetahuan baik tidak memberikan obat tradisional pada anak dengan diare. 
Sebanyak 34 responden $(59,6 \%)$ yang berpengetahuan kurang didapatkan masih memberikan obat tradisional saat anak mereka diare.

Pada penelitian ini juga menemukan 41 responden $(71,9 \%)$ yang memiliki pengetahuan kurang dengan praktik kurang tepat dan hanya 2 responden (40\%) berpengetahuan baik dengan praktik tepat dalam pemberian teh manis saat anak diare seperti pada Tabel 10.

\section{DISKUSI}

Tingkat pengetahuan responden mengenai penanganan diare pada balita diukur dari skor total yang diperoleh setelah menjawab kuesioner. Tingkat pengetahuan responden dikategorikan menjadi dua menggunakan cut off point. Apabila responden dapat menjawab dengan benar pada $75 \%$ atau lebih pertanyaan di kuesioner, maka responden dikategorikan memiliki pengetahuan baik. Sebaliknya, apabila responden menjawab benar pada kurang dari $75 \%$ pertanyaan di kuesioner, maka tingkat pengetahuan responden dikatakan kurang. Dari hasil skor total dalam menjawab kuesioner $91,9 \%$ responden memiliki tingkat pengetahuan kurang dan hanya $8,1 \%$ responden yang pengetahuannya baik. Hasil ini menunjukkan bahwa ibu balita masih belum memahami mengenai diare serta penanganannya pada balita. Penelitian ini sejalan dengan penelitian Herwindasari (2014) yang menemukan 63\% responden memiliki pengetahuan kurang mengenai diare pada balita. ${ }^{7}$ Selain itu, pada penelitian yang dilakukan oleh Wulandari (2013) mengenai tingkat pengetahuan ibu yang mempunyai anak balita mengenai penanganan diare juga menemukan $83,67 \%$ responden berpengetahuan cukup dan kurang. ${ }^{8}$

Dari hasil penelitian ini diketahui bahwa mayoritas ibu balita tidak mengetahui penanganan diare secara awal. Hal ini dapat berpengaruh terhadap perilaku ibu mengenai kesehatan anaknya, karena pengetahuan atau kognitif merupakan domain yang sangat penting dalam membentuk perilaku seseorang. Ibu balita yang tidak dibekali pengetahuan lebih akan asupan cairan sebagai tata laksana kehilangan cairan dapat menerapkan pola pikir yang salah. Ibu yang sudah dibekali pengetahuan akan diare dan dehidrasi akan mengetahui penanganan tepat adalah dengan memberikan cairan, salah satunya yakni oralit. ${ }^{10}$ Selain itu, penanganan diare di tingkat rumah tangga juga dapat dilakukan dengan pemberian makan dan minum untuk balita. Apabila anak masih minum ASI, maka pemberian ASI tetap dilanjutkan. Sedangkan bagi anak yang sudah tidak minum ASI, pemberian makan dan minum tetap dilakukan dengan lebih sering untuk menggantikan cairan yang hilang. ${ }^{8}$
Pengetahuan responden yang kurang dapat diakibatkan oleh berbagai faktor yang kompleks dan saling mempengaruhi. Ada beberapa faktor yang diketahui berpengaruh terhadap tingkat pengetahuan seseorang, diantaranya usia, tingkat pendidikan, dan paritas. Pada penelitian ini, responden yang didominansi oleh kelompok usia 25-34 tahun didapatkan sebanyak 37 responden $(97,4 \%)$ yang berpengetahuan kurang mengenai penanganan diare pada balita. Hal ini sejalan dengan penelitian Purbasari (2009) mengenai tingkat pengetahuan, sikap, dan perilaku ibu dalam penanganan awal diare pada balita yang menunjukkan $88,6 \%$ responden dalam kelompok usia 26-35 tahun memiliki tingkat pengetahuan yang kurang dalam penanganan diare pada balita. ${ }^{11}$

Usia diketahui mempengaruhi daya tangkap dan pola pikir seseorang, dimana kelompok usia ini merupakan usia dimana cara berpikir seseorang telah menjadi matang dan dapat lebih mudah menerima informasi dari orang lain. Semakin bertambahnya usia seseorang akan semakin berkembang pula daya tangkap dan pola pikirnya, sehingga pengetahuan yang diperolehnya semakin membaik. Semakin tua seseorang dinilai akan semakin bijaksana, semakin banyak informasi yang dijumpai, dan semakin banyak hal yang dikerjakan, sehingga menambah pengetahuannya. Namun, seseorang dengan usia yang lebih tua tidak selalu pengetahuan, sikap, serta praktiknya lebih baik dibandingkan dengan sesorang yang lebih muda.

Menurut Notoadmojo (2005), seseorang pada usia menengah akan lebih banyak menggunakan waktunya untuk membaca, sehingga pengetahuan yang diperolehnya semakin membaik. ${ }^{12}$ Namun, pada penelitian ini justru didapatkan mayoritas responden pada kelompok usia menengah memiliki pengetahuan yang kurang. Hal ini dapat disebabkan oleh kurangnya ketersediaan media penyalur informasi seperti koran, pamflet, serta majalah kesehatan.

Berdasarkan tingkat pendidikannya, seluruh responden yang tidak bersekolah didapatkan memiliki pengetahuan kurang mengenai penanganan diare pada balita, sedangkan $16,7 \%$ responden yang berpendidikan S1/akademi memiliki tingkat pengetahuan yang baik mengenai penanganan diare pada balita. Artinya, tingkat pendidikan sangat berperan dalam penyaluran informasi kesehatan. Hal ini sejalan dengan teori yang dikemukakan Mubarak \& Chayati (2009) yang menyatakan seseorang dengan tingkat pendidikan formal yang tinggi akan memiliki tingkat pengetahuan yang lebih tinggi mengingat lebih mudahnya mengakses serta memahami informasi bagi seseorang yang berpendidikan lebih tinggi. ${ }^{13}$ 
Pada penelitian ini juga didapatkan $20 \%$ responden yang memiliki 2 anak berpengetahuan baik dalam menangani diare pada balita. Hal ini sejalan dengan penelitian yang dilakukan oleh Munggaran (2012) yang menunjukkan responden dengan jumlah anak yang lebih banyak memiliki tingkat pengetahuan lebih baik mengenai penanganan diare pada balita. Kurangnya pengalaman pada ibu balita yang memiliki anak lebih sedikit memungkinkan ibu kurang mengetahui penanganan diare yang tepat. ${ }^{4}$

\section{Gambaran Sikap Spesifik Responden Mengenai Penanganan Diare pada Balita}

Sikap responden diukur berdasarkan 10 pernyataan sikap spesifik mengenai diare dan penanganannya yang tercantum dalam kuesioner. Interpretasi sikap spesifik dilakukan dengan menggunakan Skala Likert. Apabila responden mendapat skor pada masing-masing sikap $\geq 3$ maka dikategorikan sebagai sikap positif sedangkan apabila mendapat skor dalam sikap spesifik sebesar $<3$, maka dikategorikan sebagai sikap negatif. Secara umum dari 10 aspek pernyataan sikap spesifik yang ditanyakan terdapat 8 aspek pernyataan spesifik yang menujukkan sikap positif ibu balita menanggapi masalah diare dan penanganannya. Terdapat 2 aspek pernyataan spesifik sikap yang direspon negatif oleh sebagian besar ibu balita yakni dalam menyikapi tindak lanjut saat anak buang air besar encer lebih dari biasanya maka harus segera dibawa ke rumah sakit dan menyikapi pernyataan terkait penanganan diare cukup dengan oralit saja.

Pada penelitian ini tampak bahwa sebanyak $51(82,3 \%)$ ibu balita beranggapan apabila anak yang mengalami buang air besar lebih encer dari biasanya harus segera dibawa ke petugas kesehatan. Hal ini dapat disebabkan karena anggapan dari ibu balita bahwa setiap anak yang mengalami sakit harus segera dibawa ke dokter atau ibu balita tidak mengetahui cara penanganan awal diare pada anak. Penanganan awal diare pada dasarnya dapat dilakukan di rumah dengan prinsip mencegah dehidrasi yaitu dengan pemberian cairan lebih banyak. Cairan yang dapat diberikan berupa air matang, oralit, atau dengann memberikan makanan yang mengandung banyak air (sup/bubur). Selain itu larutan oralit juga dapat dibuat di rumah dengan bahan yang tersedia di rumah yakni air, gula, dan garam. ${ }^{11}$

Pada penelitian ini juga tampak bahwa sebagian besar ibu balita beranggapan bahwa pengananan diare cukup dengan pemberian oralit saja yakni sebanyak $42(67,7 \%)$ ibu balita. Sesuai dengan pedoman WHO, selain mencegah dehidrasi, penanganan diare juga bertujuan untuk mencegah terjadinya malnutrisi pada anak dengan pola makan yang bergizi dan lebih sering dari biasanya serta melanjutkan pemberian air susu ibu. Selain itu, pemberian zinc diperlukan karena dapat menurunkan durasi episode diare dan menurunkan volume tinja saat diare. Sesuai penelitian yang dilakukan oleh Purbasari (2009) menyatakan sebanyak 88\% ibu balita tidak mengetahui suplemen zinc yang diperlukan dalam penanganan diare. ${ }^{11} \mathrm{Hal}$ ini dapat disebabkan karena kurangnya informasi/edukasi baik secara perorangan atau kelompok terkait penanganan diare secara menyeluruh pada anak balita. Selain itu, kurangnya pemberiaan zinc oleh petugas kesehatan dalam penanganan diare juga dapat menjadi penyebab masyarakat tidak mengetahui manfaat zinc.

Jika dilihat distribusi sikap spesifik ibu berdasarkan pengetahuan ibu terhadap penanganan diare pada anak balita diketahui bahwa terdapat 48 (84,2\%) ibu balita memiliki pengetahuan kurang dengan sikap negatif terhadap tindak lanjut lanjut saat anak buang air besar encer lebih dari biasanya. Selain itu, penelitian ini juga menemukan 39 (68,4\%) ibu balita memiliki pengetahuan kurang dengan sikap negatif terhadap pernyataan penanganan diare cukup dengan oralit saja. Hal ini menunjukkan bahwa terdapat kecenderungan ibu balita dengan pengetahuan baik memiliki sikap positif yang mendukung, sedangkan ibu balita dengan pengetahuan kurang memilki sikap negatif. Namun, secara statistik perbedaan ini tidak bermakna secara signifikan $(p>0,01)$. Hal ini berbeda dengan penelitian Listianingsih, dkk (2014) yang menunjukkan ada hubungan yang signifikan antara pengetahuan dan sikap dalam penanganan awal diare pada anak prasekolah di RW 12 Desa Jaya Mekar. ${ }^{15}$

Peningkatan pengetahuan tidak selalu diikuti dengan terjadinya perubahan sikap. Akan tetapi, terdapat hubungan yang positif antara pengetahuan dan sikap, yakni dengan peningkatan pengetahuan maka terjadinya perubahan sikap yang cepat. Ibu yang memiliki pengetahuan baik tentang penanganan awal diare akan cenderung mempunyai sikap yang mendukung atau positif, sebaliknya ibu yang memiliki pengetahuan yang kurang maka mereka akan cenderung mempunyai sikap yang tidak mendukung atau negatif.' Sikap ibu yang terbentuk juga dapat dipengaruhi oleh pengalaman pribadi. Pengalaman yang dialami ibu dalam merawat anaknya yang pernah mengalami penyakit diare menjadi salah satu komponen aktif terhadap suatu objek. Hal tersebut sesuai dengan teori yaitu untuk menjadi dasar pembentukan sikap, pengalaman pribadi haruslah meninggalkan kesan yang kuat. Lingkungan sekitar berupa pengalaman dari ibu lain dalam penanganan diare juga dapat berpengaruh terhadap sikap ibu. Ibu tersebut akan 
memberikan informasi kepada ibu yang belum pernah memberikan penanganan pada anak yang mengalami diare, sehingga mempengaruhi sikap ibu tersebut untuk memberikan penanganan diare anaknya yang mengalami diare. Hal ini sesuai dengan fungsi sikap yaitu penyesuaian sikap yang membantu individu. ${ }^{16}$

\section{Gambaran Responden Berdasarkan Praktik Spesifik}

Berdasarkan penelitian yang dilakukan terhadap 62 responden ibu balita pada beberapa aspek dalam praktik penatalaksanaan diare pada balita masih dalam kategori kurang. Pada penelitian ini diketahui bahwa masih terdapat praktik yang kurang tepat dalam penantalaksanaan diare terutama dalam hal tindak lanjut atau penanganan awal saat buang air besar lebih encer dari biasanya, penggunaan obat tradisional, pemberian teh manis/jus buah pada anak balita saat diare, dan tidak diberikannya zinc pada anak balita. Sebagian besar ibu balita $(56,5 \%)$ yang anaknya mengalami buang air besar lebih encer dari biasanya sebanyak sekali atau dua kali dalam sehari akan segera membawa anaknya ke puskesmas/dokter/bidan. Pada dasarnya diare berarti perubahan konsistensi buang air besar menjadi lebih encer sebanyak lebih dari 3 kali dalam sehari dengan atau tanpa darah dan lendir. ${ }^{17}$ Hal ini menunjukkan pemahaman masyarakat terkait definisi diare masih kurang.

Adanya praktik yang kurang tepat dalam penelitian ini juga tampak pada sebanyak 49 (79\%) ibu balita tidak memberikan tablet zinc pada anak balita dengan diare. Alasan sebagian besar ibu balita tidak memberikan tablet zinc pada anaknya karena mereka tidak mengetahui tentang tablet zinc dan manfaatnya. Serupa dengan penelitian yang dilakukan pada ibu balita di Puskesmas Kecamatan Ciputat, Tangerang Selatan, ditemukan bahwa 88\% ibu balita tidak memberikan tablet zinc pada anaknya saat mengalami diare. Hal ini dapat disebabkan kurangnya informasi terkait manfaat tablet zinc atau akibat kurangnya ketersediaan tablet zinc di fasilitas kesehatan sehingga tidak diberikan saat ibu balita melakukan pengobatan di fasilitas kesehatan. Oleh karena itu, masih diperlukan promosi lebih gencar terkait manfaat zinc baik di masyarakat maupun di instansi kesehatan.

Pada penelitian ini juga tampak sebanyak 44 (71\%) responden masih menggunakan obat tradisional dalam penatalaksanaan diare. Obat tradisional yang biasa digunakan oleh ibu balita dalam penatalaksanaan diare pada penelitian ini adalah daun jambu biji dan getah jarak. Penelitian yang dilakukan oleh Purbasari (2009) menyebutkan bahwa sebanyak $54 \%$ ibu balita masih memberikan obat tradisional seperti daun jambu, kunyit, dan teh pahit pada anaknya yang mengalami diare. ${ }^{11}$

Apabila praktik pemberian obat tradisional dilihat berdasarkan kategori pengetahuan dapat diketahui bahwa sebagian besar responden dengan pengetahuan kurang menggunakan obat tradisional sebanyak $34(59,6 \%)$ dan responden yang berpengetahuan baik tidak ada yang menggunakan obat tradisional $(\mathrm{p}=0,015)$. Hal ini serupa dengan penelitian yang dilakukan oleh Herwindasari (2014) yang menyebutkan bahwa terdapat hubungan yang signifikan antara pengetahuan dengan penatalaksanaan awal diare pada balita. Selain itu, Fediani juga menyebutkan semakin rendah pengetahuan ibu terkait diare maka semakin kurang tindakan ibu terhadap diare pada anak. ${ }^{7}$

Menurut teori Green (1980), bahwa perilaku itu di latar belakangi atau di pengaruhi oleh tiga faktor pokok, yakni: faktor predisposisi (pengetahuan, sikap dan tindakan), faktor pendukung (kepemilikan sarana atau kesehatan) dan faktor pendorong yang terwujud dalam sikap dan perilaku petugas kesehatan. Pengetahuan merupakan faktor predisposisi dalam perilaku seseorang. Terbentuknya suatu perilaku baru, terutama pada orang dewasa dimulai pada domain kognitif. Sebelum seseorang mengadopsi perilaku (perilaku baru), ia harus tahu terlebih dahulu apa arti atau manfaat perilaku tersebut bagi dirinya. Setelah seseorang mengetahui stimulus atau objek, selanjutnya menimbulkan respon batin dalam bentuk sikap subjek terhadap objek yang diketahui itu. Akhirnya rangsangan yakni objek yang telah diketahui dan disadari sepenuhnya tersebut akan menimbulkan tindakan terhadap stimulus atau objek. Namun dalam proses adopsi pengetahuan juga dipengaruhi oleh faktor pendukung seperti sarana prasarana dan faktor pendorong seperti dukungan tenaga kesehatan sampai terbentuknya suatu perilaku baru yang sesuai. Oleh karena itu, dalam praktik seharihari sesorang dapat berperilaku positif walaupun dengan pengetahuan dan sikap negative. ${ }^{18}$

Pada penelitian ini juga ditemukan sebanyak 44 (71\%) ibu balita masih memberikan teh manis pada anaknya ketika mengalami diare. Sesuai dengan pedoman penatalaksanaan diare oleh WHO, pemberiaan teh manis tidak dianjurkan. Hal ini disebabkan minuman yang terlalu manis dapat menyebabkan diare osmotik dan hipernatremia. Selain itu di dalam teh juga tidak mengandung garam yang berguna untuk mengganti elektrolit yang hilang saat diare. Apabila dilihat praktik pemberian teh manis berdasarkan pengetahuan ibu balita tampak bahwa terdapat kecenderungan pemberian teh manis oleh ibu balita yang berpengetahuan kurang. Pengetahuan yang baik akan 
cenderung mendorong praktik yang baik dalam kehidupan sehari-hari. Sebaliknya, pengetahuan kurang dapat mendorong terbentuknya praktik yang buruk. Oleh karena itu, tanpa didasari pengetahuan yang kuat dan benar, sulit untuk terciptanya praktik yang benar. ${ }^{19}$

\section{SIMPULAN}

Sebagian besar ibu balita memiliki pengetahuan kurang terkait pencegahan dan penatalaksanaan diare pada balita. Sebagian besar ibu balita masih memiliki sikap negatif dalam penanganan diare terkait tindak lanjut atau penanganan awal saat anak balita buang air besar lebih encer dari biasanya dan penanganan diare cukup dengan oralit. Sebagian besar ibu balita masih memiliki praktik yang kurang tepat dalam penantalaksanaan diare terutama dalam hal tindak lanjut atau penanganan awal saat buang air besar lebih encer dari biasanya, penggunaan obat tradisional, pemberian teh manis pada anak balita saat diare, dan tidak diberikannya zinc pada anak balita.

\section{DAFTAR PUSTAKA}

1. World Health Organization (WHO). Diarrhoeal Disease. 2013. Available at: http://www.who.int/mediacentre/factsheets/fs330/en/. [Cited at Juny 1,2015]

2. World Health Organization (WHO) and The United Nations Children's Fund (UNICEF). End preventable deaths: Global Action Plan for Prevention and Control of Pneumonia and Diarrhoea. France: WHO Press. 2013.

3. Farthing M, Salam M, Lindberg G, Dite P, Khalif I, SalazarLindo $\mathrm{E}$, et al. Acute diarrhea in adults and children: a global perspective. World Gastroenterology Organisation Global Guidelines. Milwaukee : WGO. 2012.

4. Kementerian Kesehatan RI. Situasi Diare di Indonesia. Buletin Jendela Data dan Informasi Kesehatan. Jakarta : Bakti Husada. 2011.

5. UNICEF. Diarrhoeal Disease. 2015. Available at: http:// data.unicef.org/child-health/diarrhoeal-disease. [Cited at Juny 1,2015$]$.

6. Departemen Kesehatan RI. Buku Saku Petugas Kesehatan: Lintas Diare. Jakarta: Bakti Husada. 2011.
7. Herwindasari E. Hubungan Tingkat Pengetahuan Ibu dengan Penatalaksanaan Awal Diare pada Balita di Wilayah Kerja Puskesmas Perumnas II Pontianak Tahun 2013. Pontianak: Universitas Tanjungpura. 2014.

8. Wulandari, Tri. Tingkat Pengetahuan Ibu Yang Mempunyai Anak Balita 1-5 Tahun Tentang Penanganan Diare Di Posyandu Sari Mulyo VI Pringanom Masaran Sragen Tahun 2013. Surakarta: Sekolah Tinggi Ilmu Kesehatan Kusuma Husada. 2013.

9. Notoatmodjo S. Promosi Kesehatan dan Ilmu Perilaku. Jakarta: Rineka Cipta. 2007.

10. Lopolisa AT, dan Pakasi TA. Faktor-faktor yang Mempengaruhi Insidens Diare Balita di Jakarta Timur. Effectiveness of Health Education. 2014:2(2): 347-52.

11. Purbasari E. Tingkat Pengetahuan, Sikap, Dan Perilaku Ibu Dalam Penanganan Awal Diare Pada Balita Di Puskesmas Kecamatan Ciputat, Tangerang Selatan, Banten Pada Bulan September Tahun 2009. Skripsi. Jakarta: Universitas Islam Negeri Syarif Hidayatullah. 2009.

12. Notoatmodjo S. Metodologi Penelitian Kesehatan. Jakarta: Rineka Cipta. 2005.

13. Mubarak WI, dan Chayati N. Ilmu Keperawatan Komunitasdan Teori. Jakarta: Salemba Medika. 2009.

14. Munggaran AI. Pengetahuan, Sikap, dan Perilaku Ibu Pengunjung Posyandu Desa Sukasari Mengenai Penanganan Diare Akut Pada Balita Tahun 2012. Jakarta: Universitas Islam Negeri Syarif Hidayatullah. 2012.

15. Listianingsih LT, Indriarini MY, Dan Sitompul HO. Hubungan Pengetahuan Ibu Dengan Sikap Dalam Penanganan Awal Diare Pada Anak Prasekolah Di Rw 12 Desa Jaya Mekar Padalarang. 2014.

16. Wawan A dan Dewi M. Teori dan pengukuran pengetahuan, sikap dan perilaku manusia. Yogyakarta: Nuha Medika. 2010.

17. Arhana BNP. Pedoman Pelayanan Medis Ilmu Kesehatan Anak RSUP Sanglah Denpasar. Edisi tahun 2010. Denpasar: Ilmu Kesehatan Anak (IKA) RSUP Sanglah. 2010.

18. Mauliku HE, dan Wulansari E. Hubungan Antara Faktor Perilaku Ibu Dengan Kejadian Diare Pada Balita Di Puskesmas Batujajar Kabupaten Bandung Barat. Jurnal Kesehatan Kartika Stikes A. Yani: 40-51. 2008.

19. Kurniati TA, Suriah, dan Rahman. Upaya Ibu Dalam Penanganan Diare Pada Anak Balita Etnis Bima di Wilayah Kerja Puskesmas Paruga Kota Bima. Makassar: Universitas Hasanuddin. 2013.

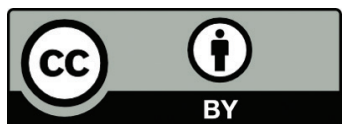

This work is licensed under a Creative Commons Attribution 